\title{
LIBRARIES: DYNAMIC ENGINES FOR KNOWLEDGE AND INFORMATION SOCIETY
}

\author{
I.M. Aliu ${ }^{1}$ and I. O. Igbinosa ${ }^{2}$ \\ ${ }^{1}$ John Harris Library, University of Benin \\ Benin City, Nigeria. \\ ${ }^{2}$ University Of Benin \\ Benin City, Nigeria.
}

\begin{abstract}
This paper took an in-depth look at key words and synonymous concepts such as libraries, knowledge and information. Thereafter the prowess of the library in all ramifications as an engine for the acquisition of knowledge and dissemination of information was copiously examined. This was done against the background of Information Communication Technology (ICT), which has undoubtedly launched the world into a new era (New World Order) reminiscence of the Industrial Revolution. The dynamism of the library in this new world can therefore be expressed in continuous learning. This paper sees the library as the logical and convenient locale for it. The paper concluded by recommending the library as a home for all and sundry information seekers - the academically famished university lecturer, the diplomat, the industrialist and the young at heart. The library indeed, as concluded in this paper should be our companion from cradle to grave.
\end{abstract}

Keywords: Libraries, Knowledge, Information and Information Society.

\section{INTRODUCTION}

The conventional approach to an academic discourse of this nature is to take cognizance of the keywords within the context of library as a dynamic engine for knowledge and information society. Through definition of such keywords and conceptual clarification, one would be better positioned to delineate concepts/terms with very thin lines and knit together others that cut across the borderline. To this end, attempt would be made to take closer look at key words such as 'Library', 'Knowledge' and 'Information' as the hub around which the entire discourse would revolve.

Before such attempt is made, let's borrow a leaf from the experience of an old student in a certain University campus about the library which remains an enigma. "Once an old student was showing a freshman round a certain university campus, as they approached the library, the freshman asked, "What's this building"? "Well", replied the old student "that's the library but it is a side issue" Nwosu (2004). The sole objective of

174 Journal of Science and Technology, Vol. 27, No. 3, December 2007 
this paper among others is therefore to prove that the library is not a side issue.

It is "the handmaid of scholarship," the pivot on which the life of the institution revolves, "the educative aorta of the institution," "the heart of the institution" the dynamic engine for knowledge and information society. (Nwosu, 2004)

Also, in the words of Louis Round Wilson (1966) the academic library:

Is the pulsing heart which is to quicken every activity that goes on upon the campus, it is the easily accessible mentor to which every alumnus, after his days of privilege within the college walls have ended should look for guidance; and it is the beacon light whose rays should illumine more and more the path of those leaders of men who are entrusted with the conversation of equality of opportunity and the solution of the problems of civilization that daily assume a greater and ever increasing degree of complexity.

The library has once been described as a growing organism; the society's dynamism therefore determines the concept of a library. It is on the above premise of the library being a growing organism that the evolving concept of the library today is replicated in a paradigm shift from a building where book and non-book materials are preserved to a "wall less" or library without wall popularly referred to as a virtual library in the USA, Canada and Mexico. This conceptual shift, is no doubt brought about by Information Communication Technology. (ICT); which has undoubtedly launched almost every facet of human endeavour into a "New World Order"

\section{New World Order in Perspective}

It is worthwhile to expatiate on the concept of a 'New World Order' in order to open up vistas for examining the library in the spectacle of that 'New World Order'. The concept 'New world order' implies a global tilt from the way people do and perceive things at one time, towards a completely new and different way of doing those things at another time, all with a view of achieving the best in all human endeavours at minimum cost in time and energy.

The 'New World Order' in the eyes of librarianship is therefore, an allusion to the inevitable drift occasioned by the advancement in technology from the professional order or ways of information gathering, access to information and dissemination to the new order/ways of performing the same tasks. For instance manual cataloguing and classification, manual bibliographic compilation and checking, ordering of books and journal titles, journal publishing are tasks; that are now electronically performed in the new world order of information technology. The phrase 'New World Order', according to Momah (1995), "is not just a contemporary catch-phrase, but has always been a recurrent issue in man's bid to perfect the world."

History has also shown that world orders have emerged most times from the ruins of war. Nevertheless, the World Order under discussion though reminiscence of the epochal changes that marked the pre and post world war eras is strictly devoid of war. It was in the form of intellectual gymnastics of some United Sates Soldiers in a bid to perfect the world; diminished national and International boundaries through high-tech communication equipment. The result of their efforts, beyond their imagination has been manifested in an evershrinking world, a world made porous, by unrestricted information flow, permeating every fabric of human society; hence the coinage global village otherwise replicated in a "New World Order".

\section{Library, Knowledge and Information Defined and Delineated}

The word 'Library' has been copiously defined above sufficient enough to serve as an opening gambit towards eliciting the concept of knowledge as it resides in the library collection.

Churchman (1971) an information system philosopher, writing in the 1970 s asserted that to 
conceive of 'knowledge' as a collection of information seems to rob the concept of all its life.....' Knowledge, he maintained resides in the user and not in the collection. It is how the user reacts to a collection of information that matters. Knowledge is information, which provides guidance for action. It comprises a fluid mix of experience, values, contextual information and expert insight that provides a framework for evaluating and incorporating new experience and information. It originates and is applied in the mind of the 'knower'. Within that understanding, "the library collection is organised so as to allow a systematic means of access to both the physical items themselves and the intellectual content of those physical items (Balakrishnan and Paliwa, 2001) The Librarian in this regard organizes information so that it can be used, and in the process knowledge is acquired; knowledge which would benefit the entire society. In organization, knowledge becomes embedded not only in document or repositories but also in organizational routine, processes, practices and norms (Information Development, 2001).

The frequent use and profuse juxtaposition of 'knowledge' and 'information' tend to make the two concepts subsumed. In order not to complicate our comprehension, it is necessary to further elaborate on these twin concepts. In this sense, the word data would be added as a related term for proper understanding.

Data consists of facts in their raw, unmanipulated form, information makes sense of the data and knowledge adds the human reaction elements. That is, knowledge internalizes and evaluates the significance of the information, and knowledge should result in decision and $l o r$ action in relation to the information.

However, Batlin (1985) says the word 'information' is a troublesome one. According to her, the academic librarian has always distinguished between 'information and knowledge'. Such that there appears to be a consensus among the academic librarian which tilts towards the basic philosophy and objective of a commitment to the organization of knowledge and the support of continuing scholarship. Still within the troublesome and confused milieu, contemporary information managers and computer specialists tend to treat all information as data. They have been technically more concerned with the technical aspects of hardware and systems than with the substantive content of "data" and its influence on systems of organization, storage, access and retrieval. The generation of electronic data is of less immediate value because comparatively few people have access to the hardware and software which are the essential means of interaction with data. (Balakrishnan and Paliwal, 2001) Hienz Von Forester trying to douse the confusion of what information is and what it is not; pointed out that what is travelling on that wire, is not information, but signals. Nevertheless, since we think we know what information is, we believe we can compress it, process it, chop it up. We believe information can even be stored and then, later on retrieved.. In this, according to him, we are mistaken. This is because a library may store books, microfiches, documents, films, slides and catalogues, but it cannot store information. For, if you turn a library upside down, no information will come out. The only way one can obtain information from a library is to look at those books, microfiches, documents, slides etc. The logical corollary is that information is much more amenable to the theory of the market than knowledge, as it can be measured, priced, sold and bought like a commodity (Balakrishnan and Paliwal,2001)

Ifidon (2005) did not mince words in expressing the lack of a unique and commonly acceptable definition of the word information. According to him, 'information is too difficult and complex to define; because what we call information is slippery and loaded with implications. However, he gave an operational definition of information as mankind's accumulated knowledge and wisdom derived from all subjects, in all forms and from all sources that could help its users to reduce their

176 Journal of Science and Technology, Vol. 27, No. 3, December 2007 
level of uncertainty. In specific terms he likened information to data processed to be of value in planning and decision-making in the execution, monitoring and evaluating of public and private sector programmes of a nation. Information society is therefore, a segment or a subset of any given community in quest of specified knowledge vital to its advancement in whatever guise at a particular point in time. Take for instance, information intended to sustain the community by keeping its members informed about their rights, the benefits to which they are entitled, organizations which exist to help them etc. differs from information needed to help managers make the right decisions, also to help the Chancellor of the Exchequer with his budget, to sustain the economic life of a community, to help business people and householders to make their tax returns, to help local government officers and councillors to provide the services which are their statutory responsibilities as economically as possible ....' ( Backwell, 1997).

It is for these reasons that Gratton (1986) pointed out that information means many things to many people and the degree of relevance of a piece of information varies according to the needs of the different individual community or audience. Reports about Nigerian's foreign reserve would be irrelevant to a local peasant farmer, as would information on the latest improved variety of cassava stems. Mankind therefore, cannot afford to live in isolation, stay aloof and watch one another at a distance. He needs to be informed about the activities of his immediate and distant neighbours. Interaction at every stratum of society is therefore imperative. According to Ifidon (2005) information is the bedrock of that interaction.

Unfortunately, in spite of the information society in which we live, information is a 'scarce and neglected resource', (Bakewell,1999). The library is at the centre of it all as an assemblage of all the knowledge and information resulting from man's endeavour, making it available to all who are interested. The next pertinent step to take at this juncture is to find out the role of the library in promoting the acquisition of knowledge relevant to the advancement of an 'information' society in the 'New World Order'. In a nutshell, information in the New World Order is an evocation of a shrinking world now wearing the garb of a celebrated coinage "global village".

The librarians, in the New World Order are ostensibly confronted with the palpable fear of obsolesce. When Lancaster (1978), a foremost apostle of paperless society in the $20^{\text {th }}$ century, prophesied a new world order replete with advancement in information technology and its threat to librarianship even at the erosion of its nomenclature from 'librarian' to 'Cyberian' i.e.(Cyberspace librarian) or hybrarian i.e. (hybrid librarian) it was taken with a pinch of salt. All these were manifestations of a changing world information order. The American Library Association (2001) has duly acknowledged this change through its publication, the "Cybrarian's Manual'.

\section{Libraries: Dynamic Engine for Knowledge and Information Society}

It is incontrovertible fact that no institution grows above its library. The product of an institution is thus the sum total of the worth of its library. The library is imbued with professionally trained men and women ready to interpret documents and make knowledge and information available to its seekers. Knowledge and information is so vital to the economic, political and social development of any nation that a nation bereft of knowledge and information is doomed and is standing on the precipice of extinction. It is in realisation of the place of information that Ifidon (2005) views information as both an organic part of development and a potent instrument for furthering that process of development. In this context, development refers to the degree to which a society has improved its environment in terms of its social, economic and political well being. Countries of the world today, that have been acclaimed as advanced or developed are so regarded because of the quantum of information at their disposal. Such 
countries have intelligently developed their human resources, took advantage of the fact that today's progress is inextricably tied to yesterday's achievements. In recognition of this fact there has been an unfettered recourse to the library. That is why, anywhere in the world today, men and women of repute and fame have had a relentless romance with the library by scavenging into the womb (library) of history to get the relevant knowledge and information that would contribute to the development of the society. The library is therefore, nothing but the oasis of knowledge and information that must be well explored by all and sundry in order to keep abreast with the rapidly growing global information society.

\section{Libraries: Dynamic Engine for Knowledge and Information Society in the New World Order}

Looking at the library as a dynamic engine, for knowledge and information; through the spectacle of the new world order, posses an innovation. That perhaps would take us to another dimension. This dimension is a necessary step that must be given prominence in the face of a world made porous, loose and boundless because of the unprecedented degree of Information Communication Technology (ICT) permeating the new world.

As observed by Sebastian (2001) "It is impossible not to be a part of this awesome process of change." In this changing circumstance of a new world order; can the library still enjoy its erstwhile monopolistic status of a dynamic engine for acquisition of knowledge and the creation of an informed society?

The omnipresence of information communication technology in modern society is a sign of a new framework for the personality, with a strong educational flavour. The bombarding of citizens with an ever-growing volume of information, and above all the extension of the library beyond the four walls has created the impression that access to knowledge is now free, and that social distances could be eliminated and professional secret revealed. Concepts such as the "library without walls," "hybrid library," "electronic library," alternative schooling," the computerised society" and the "global village" reflect a permanent form of access to knowledge. The library in this regard whether old or new age remains a veritable engine for the acquisition of knowledge and information. The library in this era presents a 'new man' capable to varying degrees of being fashioned day by day in his thinking, because of the widespread and unrestricted access to knowledge and information. The society becomes better for it as intellectual standardization becomes entrenched, generally to higher degree than in the era of the orthodox concept of librarianship. Not holding the traditional library practice in contempt, the widespread use of ICT has diminished the erstwhile distinctive qualities of school, college and university libraries in virtually all societies, as they inadvertently tend to renounce their monopoly on acquisition of knowledge and dissemination of information, now that ICT is doing so much of the school's traditional job. This apparently raises question of rethinking the library's function in any set up perhaps for this reason the nomenclature librarian is gradually being renamed as 'Cybrarian.'

In this New World Order of exponential increase in the volume of information, Batt (1999) views the trend as having all the making of social revolution that is perhaps on the scale of industrial revolution. However, with an air of optimism, Batt, opined that such revolution would bring new opportunities to the individual and world society in ways that may not be fully comprehended for 40-50years.

As stated earlier, changes are the very essence of our society. That is why Sharma (2001) described societal evolution in terms of three waves: the first being the agricultural phase, followed by the industrial phase, and finally the present which is precisely the new world order as the third wave. Bell (1974) describes this era as the postindustrial society, which is involved in knowl-

178 Journal of Science and Technology, Vol. 27, No. 3, December 2007 
edge and service industries. The commodity produced by these industries is no doubt 'knowledge and information'. The library ostensibly a service-oriented institution is at the centre stage as a trafficker of knowledge, a dynamic engine for the acquisition and dissemination of information. The challenges this post-industrial society pose to the library with ICT could be described as ominous.

In this, Corral (1995) wrote that 'local area networks offer opportunities for end-users with sophisticated and powerful workstation on their desks to search without going through a library or information professional'

In support of Corral's position Augustine (2001) states that 'it is true that both librarians and readers are caught up in a fast changing information environment; as electronic communication and publication are transforming research, scholarship, teaching and learning in the $21^{\text {st }}$ Century. He therefore stressed that "technology trends and developments have to determine the future shape of library and information services and management"'.

It is against this backdrop that Baby (2001) viewed librarians vis-a-vis their traditional libraries as permanent archives of scientific achievement and guaranteed source of access to their records....' but with the new concept of on-line information sources, the emphasis has shifted from ownership to access. This new trend of information anywhere, everywhere he emphasised has been made possible only because of tremendous development in computer hardware and communication technology thereby making the process of quick retrieval of information less cumbersome.

What this scenario depicts, is that the New World Librarian in the changing library scene has to among others wear the garb of an information scientist who should act as a gateway to future and the past; also as knowledge manager, as organizer of networked resources; as collaborators with technology resource provider and above all as an individual information consultant.

For libraries to continue in their relevance as dynamic engines for knowledge and information society Sharma (2001] states that "the libraries have to adapt to the introduction of technology e.g a change in organizational structure is warranted: such a change he stressed would be determined by the objectives of the library and the services expected of it. Inter (1991) in his contribution to the sustained effort of the library as dynamic engines for the growth of knowledge and information opines that "in the New World Order libraries/librarians would have to change their orientation from library-centred to client centred. In the same vein the organizational scope would reflect this change with a tilt from the three traditional divisions - viz, user services, technical services and administration to the user groups, subject or long-range, which will be conducive to providing optimal services. However, Drake (1983) differs in his opinion in the sense that an organizational change would be difficult to bring about.

At this juncture, it must be emphasised that the benefits accruable from information communication technology are not what is being contested; but the threat it poses to the library in its erstwhile domineering posture as a veritable tool for the growth of knowledge and sustenance of an information society. It is incontrovertible today, that with the advent of electronic information revolution, an information seeker is immediately plugged into a world wide web of unregulated and uncensored digitized information network, thus empowering the information seeker against the traditional institution of the library. For instance, Internet browsing centres are being established almost in every street all over Nigeria. The patronage of these centres is on the increase as well as the awareness of their inherent provision. The virtual library concept is therefore felt realizable because of the popularity of the Internet. As observed by Augustine (2001) "Today almost everyone uses the Internet, persons of every age, occupation and income bracket. People look up 
Internet from home, school or college, library and workplace. About 30-40 million users are there and about 1 million new users are added each month. About 73 websites are added to the World Wide Web each day (Kasser, 1998). What all of these portend is a threat to the status of the library as a dynamic engine for knowledge and information society. The way out of this dilemma is paradigm shift, adaptation and realignment with the New World of information order. (Kasser and Barbara,1998).

\section{Libraries: Dynamic Engines for Life Long Learning}

Life-long learning is necessary, and the library is the logical and convenient locale for it. The need for lifelong learning has become increasingly important in view of the social and economic changes taking place in the Nigerian society and indeed the world over (Okunkpon 2005] As it has been said above, change is of essence for continuous relevance, especially in the face of rapid technological advancement. As a result, the learning process becomes a continuous one, in order to keep abreast with new ideas, new knowledge, new values and new practices to suit these technological, social and economic changes. What is then lifelong learning?

The concept of lifelong learning according to Christopher and Arthur (1991) is a process of learning throughout one's life. Similarly, Longworth and Davies (1996) gave a working definition of lifelong learning as a "development of human potential through a continuously supportive process which stimulates and empowers individuals to acquire all the knowledge, values, skills and understanding they will require throughout their life time..."

Several reasons have been adduced for the increased interest in the promotion of lifelong learning. Among these are social, economic and cultural changes. They arise from the phenomenon of change that is a major element in contemporary life Okunkpon (2005). Everybody requires one form of information or the other and in equal access. Citizens, whether literate or illiterate need information on modern techniques of agriculture, commerce, health, politics and human rights as basic necessity of life, information as an essential commodity to which individuals in every society should have unrestricted access Uluocha (2004) and Atinmo (2000) on the other hand state that access to information is vital if an individual is to function effectively in the present day information age. To that extent libraries need to cover a wide area of life, be it political, economical, social and cultural aspects so as to cater for the information needs of the people and thus promote lifelong learning.

For meaningful learning to take place the place of the library as the foremost dynamic engine that promotes knowledge and an informed society cannot be glossed over. The library in this regard provides the ideal institution for both democratic and accountable governance that encourages development and information to the local government systems, disseminate government policies to the public as well as initiate and implement government programs, libraries provide users with information and other reference materials such as government reports, bills discussed in National Assembly, budget speeches, research information for project proposals and educate the community which eases the implementation of government policies( Uluocha, 2004).

Libraries are essential component of a democratic society because they promote freedom of information that is vital for education. Its services contribute to the development and maintenance of intellectual freedom and help safeguard basic maintenance of values and universal civil rights. Legislative and law libraries for instance, give our legislators the opportunity to update their knowledge and also obtain data necessary for decisionmaking. The library in its role as a dynamic engine for lifelong learning provides materials that give legislators information on past legislation on matters affecting their constituencies and also guide them in passing new laws. 


\section{Libraries: Dynamic Engines for Cultural Transmission.}

The role of the library as an institution for the preservation of culture is familiar to librarians. Thus, a library of unique style is an icon of cultural intellect and a totem to the totality of knowledge (Uluocha, 2004)

Shera (1972), while espousing the cultural role of the public libraries stressed that 'library is one element in the total communication system by which a society is held together and culture is created and maintained'. For instance a nation like Nigeria with diverse socio-cultural background was brought together by the whims of the colonialists to function as one entity. A form of education that would aim at integrating the diverse nationalities should be pursued vigorously through the library. The relevance of the library as a dynamic engine to link disparate cultures within the entity called Nigeria cannot therefore, be over-emphasised.

\section{CONCLUSION}

From the above, there is no doubt that the dynamism of the library as an engine for knowledge and a creator of an unfettered information society has been exhaustive; through conceptual clarification of synonymous concepts. The prowess of the library in this role also has been highlighted in the emerging New World Order brought about by information communication technology (ICT). Not left out is the conventional task of promoting lifelong learning, which the library is at the centre stage.

\section{RECOMMENDATION}

From the foregoing, the library is strongly recommended as a home for all - home for the academically famished lecturer, whose quest is to reach the top i.e. (to become a professor, the peak of academic), home for the industrialist, home for the diplomat, home for the young whose tabula rasa needs to be engraved with knowledge, wisdom and truth needed to nurture him to an accomplished individual in all endeav- ours. It is only the library being a dynamic engine for knowledge and information society that all these wealth-creating ingredients are cultivated. So, all who are desirous of bumper harvest in life should cultivate no where else, but in the library.

\section{REFERENCES}

American Library Association (2001) In: Augustine, C.A. Digital Revolution Syndrome and libraries in Devarjan,G.D. New Challenges in Librarianship. New Delhi: Ess Ess Publication, p.24

Atinmo, M.I.(2000) 'Strategies and Tools for Library and Information Service Delivery for Visual Impaired Persons in Nigeria in the New Millennium in a Compendium of Paper presentations at 2000 NLA Annual National Conference and AGM25th-30 ${ }^{\text {th }}$ June,pp.9297

Augustine, C.A.(2001) Digital Revolution Syndrome and libraries In Devarjan,G New Challenges in Librarianship. New Delhi: Ess Ess Publication.p.14

Baby,M.D.(2001) Challenges of Information professionals in the changing environment.In Devarjan G. (2001) New challenges in Librarianship. New Delhi: Ess Ess Publications.pp.90.

Bakewell, K.G.B.(1997) Managing User-Centred Libraries and Information Services. London: Mansell Publishing Ltd. pp.1

Balakrishnan, S and Paliwal P.K. (2001). 'Future Libraries'. New Delhi: Anmol Publications PVT.Ltd p.90

Batt, C.(1999). I have seen the Future and IT works, Library Review. 48 (1):11

Batlin, P. (1985). 'The electronic library: a vision for the future'. In Liebaers, H. New Information technologies and Libraries. Dordrecht: Kluwar Academic.pp.201

Bell, D. (1974). The Coming of Post-Industrial Society: a venture in social forecasting. New Delhi: Arnorld-Heinnemann.P.126 
Christopher, K.K. and Arthur,J.C. (1991), In Okukpon, L.A. 'Lifelong Learning in Nigeria: Needs and Structures', Nigeria Journal of Adult and lifelong Learning. Journal of the department of Adult Education and Extra Mural Studies, Universities of Benin, Benin city 1(1) p.14

Churchman, W. (1971). In Malhotta, Y. "Knowledge Management in Inquiring Organizations," The Proceedings of $3^{\text {rd }}$ Americas Conference on Information Systems. (Philosophy of Information system Minitrack); Indianapolis August 15-17 1997.pp 10

Coral, S. (1995). An evolving service: Managing Change. In Demsay, L. Networking and Future of Libraries: Managing the Intellectual Record an International conference at the University of Bath. London: Library Association Pp.45-61

Drake, M.A.(1983).Technological Innovation and Organizational Change, J. Library Administration 19(3/4):p39

Feather, J. and Sturges, P.(1997). 'International Encyclopaedia of Information and Library Science, London: Routledge.

Gratton, P.(1986). 'Information as a Social Need: the public librarian's view'. In Information 85: Using Knowledge to shape the future. Proceeding's of a Conference Organized by the Joint Consultative Committee of Aslib: the Association for Information Management, Institute of Information Scientists, Library Association, Society of Archivists, Standing Conference of National and University Libraries. London: Aslib in association with the Library Association.

Ifidon, S.E. (2005). Information Rules the World in Proceedings of Selected Papers of the Cataloguing, Classification and indexing section of the Nigerian Library Association.pp115,116
Inter, S.(1991) Education for the Dual Role Responsibility of an access Services librarian In Jaideep S.(2001) Professional Competence in Modern Libraries. New Delhi: Authors press, p.107

Kasser, B. (1998). Using the Internet. In Devarjan, G.[2001] New Challenges in librarianship. New Delhi: Ess Ess Publications p.14

Lancaster, F.W. (1978). Towards Paperless Information Society In Feather, J. and Sturges, P. [1997] International Encyclopaedia of library and information science. London: Routledge p.268.

Lancaster, F.W. (1979). Wither Libraries, College and Research Library, Vol. 40 pp. 45-57.

Longworth, N and Davies, K (1996). Lifelong Learning: New Vision, New Implications, New roles for People, Organizations, Nations and Communities in the $21^{\text {st }}$ century. London: Kegan Page Lit.p. 21

Mesthene, E. G.(2001). Technological Changes: its impact on men and society. In Sharma Jaideep (2001). Professional Competence in Modern Libraries. New Delhi: Authors Press.

Okukpon, L.A. (2005). 'Lifelong Learning in Nigeria: Needs and Structures', Nigeria Journal of Adult and Lifelong Learning. Journal of the department of Adult Education and Extra-moral Studies, University of Benin, Benin City, Nigeria. 1(1).p.14

Sebastian, M. C. (2001). 'Information Policies in Spain: towards the New Information society'. International Journal of Library and Information Services 51 (1):p.49

Sharma, J. (2001). Professional Competence in Modern Libraries. New Delhi: Authorspress.p. 3

Uluocha, A. (2004). 'From Cradle to Grave: Libraries as Agencies for Lifelong Learning". Library Focus: A Journal of the Nigeria Library Association. 22

182 Journal of Science and Technology, Vol. 27, No. 3, December 2007 
UNESCO (1975). Final Report of Seminar on Structures of Adult Education in Development Countries with Special Reference to Africa, Nairobi: February 3.
Vincent S. and Norman S. K. (1999). All that Glitters: prospecting for Information in the Changing Library World. Stamford: Jai Press Inc. 